\title{
Effects of a Rest-Rotation Grazing System on Wintering Elk Distributions at Wall Creek, Montana
}

\author{
Julee Shambart, ${ }^{1}$ Fred King, ${ }^{2}$ and Kelly Proffitt ${ }^{3}$ \\ Authors are ${ }^{1}$ Research Intern, ${ }^{2}$ Wildlife Area Manager (retired), and ${ }^{3}$ Research Biologist, Montana Department of Fish, Wildife, and Parks, \\ Bozeman, MT 59718, USA.
}

\begin{abstract}
The large-scale influence of livestock grazing in the western United States generates a need to integrate landscape management to incorporate both wildlife and livestock. The purpose of this project was to evaluate the effects of four different grazing cells (spring grazing, summer growing-season grazing, fall grazing, and resting) on wintering elk resource selection within the Wall Creek range in southwest Montana. We collected biweekly observations of elk (Cervus elaphus) numbers and distributions across the winter range from 1988 to 2007. Using a matched-case control logistic regression model to estimate selection coefficients, we evaluated the effects of annual green-up conditions, winter conditions, landscape features, and grazing treatment on elk group resource selection within the grazing system. We found that within the grazing system, elk groups preferentially selected for rested pastures over pastures that were grazed during the previous spring (1 May- 1 June), summer (1 June-15 July), and fall (15 September-30 September). The strength of selection against the pasture grazed during the summer growing season was strongest, and pastures grazed during the spring and fall were selected for over the pasture grazed during the summer. The number of elk utilizing the grazing system increased in the $19 \mathrm{yr}$ following implementation of the grazing system; however, total elk herd size also increased during this time. We found no evidence that the proportion of the elk herd utilizing the grazing system changed following implementation of the rest-rotation grazing system. Wintering elk group preference for rested pastures suggests rested pastures play an important role in rotation grazing systems by conserving forage for wintering elk. Additionally, rested pastures provide important cover for a host of other wildlife species. We recommend wildlife managers maintain rested pastures within rotation grazing systems existing on ungulate winter range.
\end{abstract}

\section{Resumen}

La influencia a gran escala del ganado en pastoreo en el oeste de los Estados Unidos genera una necesidad de integrar el manejo del paisaje e incorporar tanto fauna y ganado. El propósito de este proyecto fue evaluar los efectos de cuatro células diferentes de pastoreo (pastoreo en primavera, pastoreo durante la época de crecimiento en el verano, pastoreo en el otoño y descanso) en la selección de recursos de los elks en el pastizal de Wall Creek en el Suroeste de Montana. Se colectaron observaciones cada dos semanas del numero y distribución de los elks (Cervus elaphus) en el pastizal durante el invierno desde 1988-2007. Se utilizaron modelos de casos regresión de pares para estimar los coeficientes de selección, evaluamos los efectos de las condiciones de crecimiento anual, condiciones del invierno, características del paisaje, y los tratamientos de pastoreo en la selección de los recursos del grupo de elks dentro de los sistemas de pastoreo. Encontramos que dentro de los sistemas de pastoreo, el grupo de elks seleccionan preferencialmente potreros descansados sobre los potreros que fueron pastoreados previamente en primavera (1 Mayo1 Junio), verano (1 Junio -15 Julio), y otoño (15 de Septiembre- al 30 de Septiembre). La fuerza de la selección contra los potreros pastoreados durante la condiciones de crecimiento en el verano fue la más fuerte, y los potreros pastoreados durante la primavera y otoño fueron seleccionaron sobre los potreros pastoreados durante el verano. El número de elks que utilizaron el sistema de pastoreo se incrementó en 19 años después de la implementación de los sistemas de pastoreo; sin embargo, el tamaño total del hato de elks también se incrementó durante este tiempo. No se encontró ninguna evidencia que la proporción del hato de elks que utilizaron los sistemas de pastoreo cambio después de la implementación del sistema de rotación del descanso. La preferencia del grupo de elks durante el invierno de los potreros descansados, sugiere que los potreros descansados tienen un papel importante en los sistemas de rotación por medio de la conservación de forraje para los elks durante el invierno. Además, los potreros descansados, proporcionan la cubierta importante para otro tipo de especies silvestres. Recomendamos a los manejadores de fauna silvestre que mantengan potreros en descanso dentro de los sistemas de rotación que existen en el invierno para el uso de ungulados.

Key Words: Cervus elaphus, livestock grazing, resource selection, ungulate winter range, Wall Creek Wildlife Management Area

\section{INTRODUCTION}

The Montana Dept of Fish, Wildlife, and Parks, Federal Aid in Wildlife Management provided funding for this project.

Correspondence: Kelly Proffitt, Montana Dept of Fish, Wildlife, and Parks, 1400 South 19th St, Bozeman, MT 59718, USA. Email: kproffit@@mt.gov

Manuscript received 11 August 2011; manuscript accepted 31 October 2011.
Livestock grazing is an important land management practice in the western United States. As such, it is valuable to integrate wildlife management with livestock grazing systems. Wildlife and livestock managers have designed and employ a variety of grazing systems that attempt to increase forage availability for wildlife while maximizing livestock grazing opportunities 
(Hormay 1970). However, the long-term impacts of these grazing systems on wildlife have not been thoroughly evaluated (Krausman et al. 2009). There has been debate about how livestock grazing affects winter range for elk and other wildlife (Alt et al. 1992; Wuerthner 1992; Fleischner 1994; Sayre 2009; Sullivan 2009), with recent debate focusing on the merits of different grazing systems (Briske et al. 2008; Brown and Kothmann 2009; Krausman et al. 2009). From the perspective of wildlife managers, decreases in standing-dead vegetation coinciding with increases in nutritional content are potential benefits of livestock grazing systems, whereas decreases in overall available forage could be a drawback. However, effects of livestock grazing on ungulates are influenced by environmental and grazing system factors, making it difficult to generalize across systems. Further, the influences of seasonal and temporal variations in grazing treatments within a grazing system may have contrasting effects on forage availability for ungulates, also making the effects of grazing on ungulates difficult to evaluate.

In the absence of grazing, standing dead vegetation can build up in a pasture making the area less desirable for grazers due to the abundance of unpalatable structural plant material (Ganskopp et al. 1992). Grazing removes older leaves and stems, stimulating new growth and producing more nutritious young leaves (Detling et al. 1979, McNaughton 1983), which may increase palatability for grazing animals. Additionally, several studies have found that grazing can increase total aboveground plant nitrogen concentrations (Coppock et al 1983; Jaramillo and Detling 1988; Coughenour 1991; Merrill et al. 1994). However, these nutritional increases may coincide with decreases in overall plant biomass, depending on the grazing intensity and geographical location (Milchunas and Lauenroth 1993).

The purpose of this project was to investigate the effects of four different grazing cells within a grazing system on wintering elk (Cervus elaphus) resource selection at Wall Creek in southwestern Montana. The core of the Wall Creek elk winter range is within the Wall Creek grazing system. The rest-rotation principles guiding the grazing system were developed to enhance soil and vegetation, maintain high-quality forage for wintering elk, and enhance the desirability of the publically owned portion of the winter range to alleviate game damage problems on adjacent private lands (Hormay 1970, Alt et al. 1992). Here, we evaluate effects of four different grazing cells (spring grazing, summer growing season-grazing, fall grazing, and resting) within a grazing system on wintering elk resource selection within the grazing system. We predicted that wintering elk would select for areas that were rested during the previous growing season over areas that had been grazed during the growing season, and that the strength of selection for rested pastures over grazed pastures may be affected by weather conditions during the growing season. Additionally, we evaluate changes in the proportion of the population utilizing the grazing system over the $19 \mathrm{yr}$ following implementation of the grazing system.

\section{METHODS}

\section{Study Area and Grazing System}

The Wall Creek elk winter range is located in the Madison Valley in southwestern Montana (Fig. 1). The core of the winter range is located within the Wall Creek Wildlife Management Area

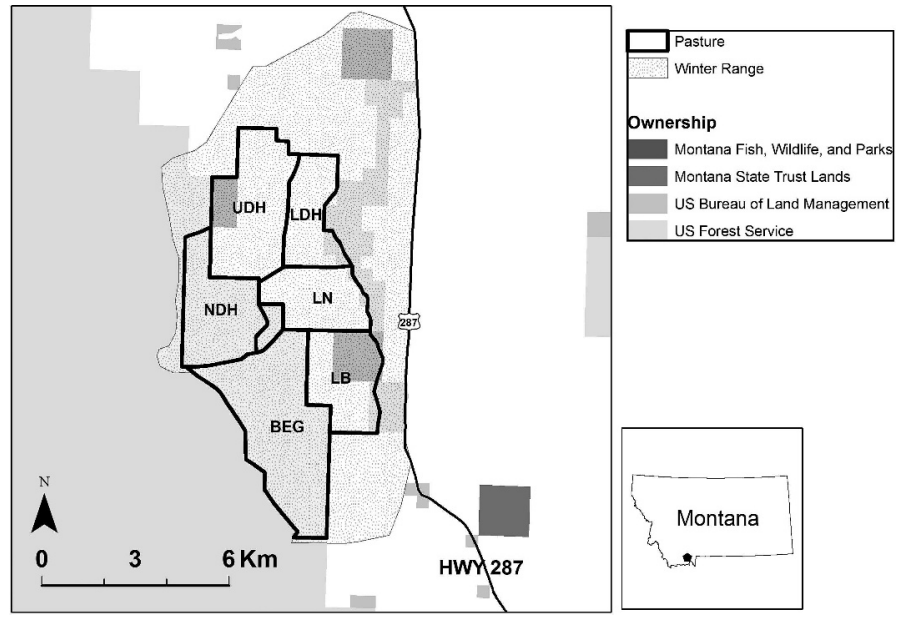

Figure 1. The Wall Creek elk winter range is located in southwestern Montana. The winter range includes Wall Creek Wildlife Management Area, an area owned by Montana Fish, Wildlife, and Parks, as well as adjacent privately owned ranchlands and lands owned by the US Forest Service, the US Bureau of Land Management, and the State of Montana. The grazing system includes six pastures within the elk winter range and an additional four higher elevation pastures (not shown) that are not used by elk during winter. The six pastures overlapping the elk winter range include three low-elevation pastures (Lower Dry Hollow [LDH], Lower Nickerson [LN], and Lower Bobcat English Gorge [LB]) and three mid-elevation pastures (Upper Dry Hollow [UDH], Nickerson Dry Hollow $[\mathrm{NDH}]$, and Bobcat English Gorge [BEG]. A small horse pasture is located in the center of the grazing system.

(WMA), an area purchased by Montana Fish, Wildlife, and Parks (MFWP) in 1960 to protect the core of the Wall Creek elk winter range. Typical of elk winter ranges throughout the West, the elk winter range expands into private lands adjacent to the WMA that are used for livestock production, creating the potential for elk-livestock interactions. During winter, human activity within Wall Creek WMA is restricted to administrative personnel, and all roads are closed to vehicle traffic. Summer range for this herd includes primarily US Forest Service (USFS) lands to the west and southwest of the winter range and extends into the Gravelly Mountains and Idaho (Hamlin and Ross 2002). The Wall Creek elk herd has steadily increased from approximately 1200 animals in 1988 to 3000 animals in 2007. Wolves were not established within the Wall Creek area during this study, although wolves from nearby areas have moved through the area occasionally during 2000-2007.

The winter range covers an area of approximately $100 \mathrm{~km}^{2}$ of which approximately $50 \mathrm{~km}^{2}$ is within the grazing system. Long-term vegetation monitoring within the grazing system indicates pastures support a stable plant community dominated by perennial native shrub, subshrub, grass, and forb species (MFWP, unpublished data, 2009). Bluebunch wheatgrass (Pseudoroegneria spicata [Pursh] Á. Löve), prairie junegrass (Koeleria macrantha [Ledeb.] Schult.), Sandberg bluegrass (Poa secunda J. Presl), and threadleaf sedge (Carex filifolia Nutt.) are the dominant grass species. Crested wheatgrass (Agropyron cristatum [L.] Gaertn.) and smooth brome (Bromus inermis Leyss.) are also present in some areas. Prairie sagewort (Artemisia frigida Willd.) is the dominant subshrub and green rabbitbrush (Ericameria teretifolia [Dur- 
and \& Hilg.] Jeps.), rubber rabbitbrush (Ericameria nauseosa [Pall. ex Pursh] G. L. Nesom \& Baird ssp. consimilis [Greene] G. L. Nesom \& Baird) and silver sagebrush (Artemisia cana Pursh) are the most common shrubs. Soil surface data show that soil movement or loss are not a concern at this time. Lesser spikemoss (Selaginella densa Rydb.) is the dominant moss species present and likely an artifact of historical farming and grazing practices. Bare soil is not increasing in the grazing system (MFWP, unpublished data, 2010).

Before 1960, the area was privately owned and intensively grazed by cattle year-round. Following purchase of the Wall Creek WMA by MFWP, the area was rested from all livestock grazing from 1960 until 1982, while grazing continued on surrounding private ranchlands. In 1984, MFWP initiated experimental grazing systems within the WMA. The current rest-rotation grazing system, which includes the Wall Creek WMA as well as adjacent USFS lands, was fully implemented in 1988. Under the current grazing system, 700 head of cattle are grazed in the Wall Creek grazing system. Pasture sizes range from 386 ha to 1368 ha, for a range of 0.57 ha to 1.94 ha per animal unit month.

The grazing system is based on 10 pastures arranged along an elevation gradient ranging from $1875 \mathrm{~m}$ to $3000 \mathrm{~m}$ (Fig. 2; see Alt et al. 1992 for additional details). The three low-elevation pastures, each within the WMA, and three midelevation pastures, two within the WMA and one owned by USFS, provide winter habitat for elk. The four high-elevation pastures, owned by USFS, provide summer habitat for elk. In a given year, one set of lowelevation, midelevation, and high-elevation pastures are grazed by moving cattle up the elevation gradient during the growing period and one set of high-elevation, midelevation, and lowelevation pastures are grazed by moving cattle down the elevation gradient during the post-seed-ripe period. The third set of lowelevation, midelevation, and high-elevation pastures, plus the extra high-elevation pasture, are rested to provide forage growth for ungulates. Cattle are brought into the low-elevation pasture from approximately 1 May-1 June (spring grazing treatment). Low-elevation grazing is timed to allow some regrowth of nutritious forage post-cattle grazing and therefore provide some forage for wintering ungulates. From approximately 1 June- 15 July, cattle graze the midelevation pasture (summer grazing treatment). This treatment is designed to provide nutritious forage to cattle during the growing season and expected to reduce forage availability for wintering ungulates. From 15 July until seed-ripe, as the green-wave moves up the elevation gradient, cattle graze the high-elevation pastures. This treatment is also designed to provide nutritious forage to cattle during the growing season, and this area is not considered winter range for ungulates. After seed-ripe, cattle are moved to a second high-elevation pasture where they remain until 15 September. On 15 September, cattle are moved to the midelevation pasture for $1 \mathrm{wk}$ (fall grazing treatment), then the low-elevation pasture for $1 \mathrm{wk}$ (fall grazing treatment). These short-duration fall treatments are expected to result in only a modest reduction in forage available to wintering ungulates. On 30 September, cattle are moved off the grazing system to private lands.

\section{Data Collection and Evaluation}

From 10 December-15 April of 1988-2007, we conducted surveys of the Wall Creek elk winter range every 7-14 d. We

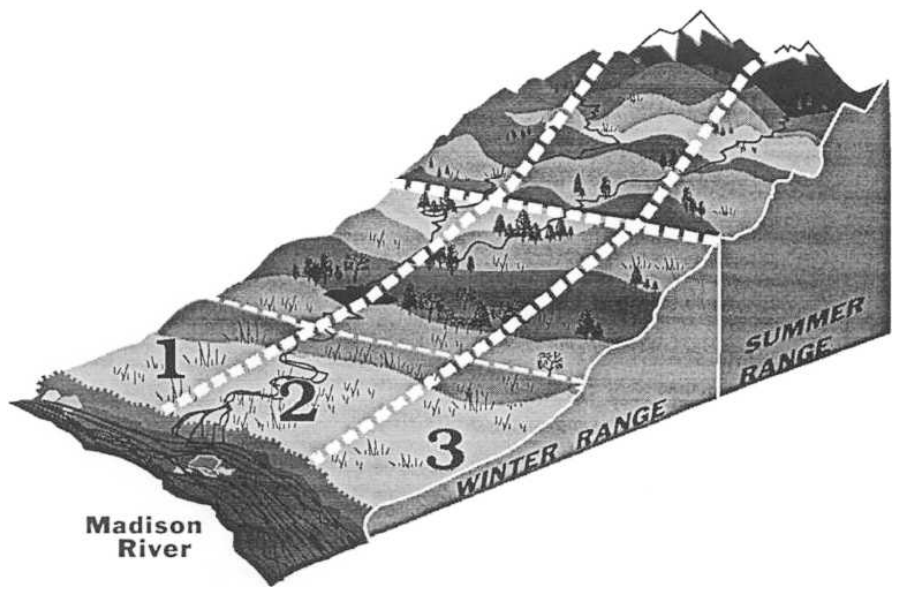

Figure 2. Schematic of the Wall Creek grazing system. Cattle are moved onto one of the low-elevation pastures on approximately 1 May and graze until 1 June (spring grazing treatment). Cattle are then moved up to the midelevation pasture and graze until 15 July (summer grazing treatment). From 15 July through seed-ripe, cattle are grazed in two high-elevation pastures. A fourth high-elevation pasture is not shown in this figure. On approximately 15 September, cattle are moved down the elevation gradient through a midelevation and low-elevation pasture for 1 wk each and removed from the grazing system on 30 September (fall grazing treatment). The remaining three pastures are rested through the entire season. The Wall Creek grazing system low-elevation and midelevation pastures are winter range for the Wall Creek elk herd.

surveyed the grazing system on 374 d from 1988 to 2007 . Surveys were conducted from four designated areas along the boundary of the WMA and from a nearby highway using a spotting scope. Elk group locations and the number of elk per group was recorded on a hard-copy topographic map and digitized into a geographic information system. A single observer (F. King, second author) conducted more than 95\% of all surveys throughout the study. The topography of the area provides excellent visibility for counting elk, and comparisons of ground and aerial data indicate ground counts were accurate. Cattle were not present in the area during the winter elk observation period, therefore, elk social avoidance of cattle was not a factor affecting elk distributions.

First, we evaluated the effects of landscape attributes, grazing unit (spring grazing, summer growing-season grazing, fall grazing, and resting), growing-season conditions, and snowpack on elk group resource selection within the grazing system. We developed a priori resource selection models representing hypotheses regarding effects of grazing treatments and other factors on elk group resource selection. We interpreted the coefficient estimates from the top-ranked resource selection models to evaluate our predictions regarding the effects of grazing treatments on elk resource selection. To investigate factors affecting elk group resource selection within the grazing system, we compared used locations recorded by observers to randomly generated available locations. We treated the elk group as the sample unit, rather than each individual animal within the group, because each individual did not independently select for a given location (i.e., locations of animals within the group were dependent on location of other group members). We considered the centroid of each group location 
as the used location. Twenty available locations were randomly generated within the grazing system for each used location. Available locations were assigned the time-varying attributes of the corresponding used location.

To account for non-grazing-treatment effects, we included covariates related to landscape attributes, elevation, time of year, and weather in our modeling exercise. We evaluated the effects of four landscape attributes potentially affecting elk resource selection: vegetation type, elevation, pasture, and distance to forested cover (Mao et al. 2005; Messer et al. 2009; Proffitt et al. 2011). We used the 2001 national land cover dataset ${ }^{1}$ to broadly classify vegetation type as grassland, shrubland, forested area, and other (rock, water, etc.) We estimated elevation from a 30-m digital elevation map. We created a 30-m grid across the study area and estimated the distance to the nearest forested cover. The study area was divided into six different pastures (Fig. 1). The six pastures overlapping the elk winter range include three lowelevation pastures (Lower Dry Hollow [LDH], Lower Nickerson $[\mathrm{LN}]$, and Lower Bobcat English Gorge [LB]) and three midelevation pastures (Upper Dry Hollow [UDH], Nickerson Dry Hollow [NDH], and Bobcat English Gorge [BEG]). Preference for individual pastures, regardless of the grazing treatment applied in a given year, was evaluated to account for underlying differences in elk selection for different portions of the grazing system. We evaluated day of the season as an attribute potentially affecting elk resource selection. We evaluated the effects of two weather variables on resource selection: snow water equivalence (SWE) and Palmer Drought Severity Index (PDSI). SWE integrates the depth and density of snowpack into a measure of the amount of water contained within the snowpack, and was measured at the Beaver Creek, Montana, snowpack telemetry site. We evaluated the interactive effects of SWE with vegetation type to represent the hypotheses that the strength of selection for different vegetation types varied as SWE varied. We obtained PDSI values for Montana Climate Division 2, which included the entire study area (National Climate Data Center 2010). PDSI integrates precipitation, evapotranspiration, soil moisture, and temperature into a single metric of annual variability of regional climate. We averaged the monthly PDSI values for May-July each year to index growingseason conditions during the previous spring and summer.

We evaluated the effects of four different grazing cells on wintering elk resource selection within the grazing system: spring grazing (1 May-1 June), summer grazing (1 June-15 July), fall grazing (15 September-30 September), and resting. Based on the grazing rotation within a given year, we assigned each elk group location the appropriate grazing unit based on the pasture it was located in during a given year. We predicted that because spring grazing is expected to remove standing dead vegetation and allow some regrowth of nutritious forage (Frisina and Morin 1991), elk group selection for the spring-grazed pasture the following winter would be greater than selection for the summer-grazed pasture, but less than selection for the rested pasture. Additionally, we predicted that elk groups would select against pastures grazed during the summer because grazing during the growing period would reduce the amount of nutritious forage and not allow ample time for regrowth. We expected elk groups to show some selection against fall-grazed

${ }^{1}$ http://www.mrlc.gov/ pastures because fall grazing should remove forage, although not to the degree as the summer grazing treatment. Elk groups were expected to select for rested pastures over spring-, summer-, or fall-grazed pastures because livestock would not have reduced the abundance of available forage. We also investigated an interactive effect of PDSI and grazing unit. We predicted that the impacts of the growing-season grazing unit would be greater following poor growing seasons (negative PDSI values) because in growing seasons with drought, forage production is lower and the quantity of forage consumed by cattle is proportionally greater (Holechek et al. 1982, Holechek 1988), leaving relatively little, low-quality forage for elk during winter.

Before developing our a priori model list, we screened covariates for correlations and excluded pairs with Pearson's correlation coefficients correlations $|r| \geq 0.7$ and variance inflation factors $>5$ from entering the same model. We conducted a multivariate analysis of the effects of vegetation, landscape features, and grazing unit on elk group resource selection using a hierarchal information-theoretic approach and matched case-control logistic regression (Proc LOGISTIC, SAS Institute 2000, Cary, NC; Manley et al. 2002). First, we compared 12 models representing effects of landscape features. We used Akaike's Information Criterion (AIC) to rank competing models (Burnham and Anderson 2002). Second, we incorporated landscape and vegetative features from the most supported model into four subsequent models representing effects of grazing. Used locations were matched temporally to their corresponding available locations and available locations assumed the time-varying attribute of the used location. Therefore, we could not estimate the main effects of SWE, the time-varying attribute; however, we did estimate interactive effects of SWE and non-time-varying attributes such as vegetation cover and elevation.

Finally, we evaluated if the proportion of the Wall Creek elk herd using the grazing system changed during the $19 \mathrm{yr}$ of this study. To identify potential long-term changes in elk use of the Wall Creek grazing system, we calculated the annual average proportion of the entire Wall Creek elk herd using the grazing system. We calculated the proportion of animals using the grazing system daily as the total number of elk observed within the grazing system relative to the estimated size of the entire herd in a given year. Estimated size of the herd was based on the maximum number of elk counted on the winter range each season. This count included all observed elk both in the grazing system and adjacent areas of the winter range. We predicted that if the grazing system enhanced the quality of the winter range for elk and the elk population remained relatively stable, the proportion of the population using the grazing system should have increased (assuming nutritional carrying capacity was not reached) or remained stable (assuming nutritional carrying capacity was reached) over the study period. If the grazing system reduced the quality of the winter range for elk, the proportion of the population using the grazing system should have decreased. However, a growing elk population that reaches or exceeds the nutritional carrying capacity of the system could also result in the proportion of the population using the grazing system beginning to decrease over time. We predicted increases in the elk population would coincide with a decreasing proportion of elk using the grazing system regardless of the quality of the winter range. 
Table 1. Number of variables ( $K$ ), Akaike's Information Criterion (AIC), $\triangle \mathrm{AIC}$, and Akaike model weights ( $w_{i}$ ) for a priori models describing effects of landscape features and grazing treatments on elk resource selection within the Wall Creek grazing system in southwestern Montana during the winters of 1988-2007. Vegetation was a categorical variable classified as grasslands, shrublands, forest, or other. DistCover represents distance to forested cover. Pasture was a categorical variable representing the six pastures. Four different grazing treatment effects were evaluated, the spring grazing treatment (May 1-June 1), summer grazing treatment (June 1-July 15), fall grazing treatment (September 15-September 30), and resting treatment (May 1-September 30).

\begin{tabular}{|c|c|c|c|c|c|c|}
\hline \multirow[b]{2}{*}{ Model } & \multirow[b]{2}{*}{$K$} & \multirow[b]{2}{*}{ AIC } & \multicolumn{2}{|c|}{ Within-model suite } & \multicolumn{2}{|c|}{ Between-model suite } \\
\hline & & & $\triangle \mathrm{AIC}$ & $w_{i}$ & $\triangle \mathrm{AIC}$ & $w_{i}$ \\
\hline \multicolumn{7}{|l|}{ Landscape features model suite } \\
\hline Vegetation + DistCover + Pasture & 9 & 15254.65 & 0.00 & 1.00 & 49.09 & 0.00 \\
\hline Vegetation + Pasture & 8 & 15351.04 & 96.39 & 0.00 & 145.48 & 0.00 \\
\hline Vegetation + SWE $^{1} \times$ Vegetation + Pasture & 11 & 15351.99 & 97.34 & 0.00 & 146.43 & 0.00 \\
\hline Vegetation + SWE $\times$ Pasture & 13 & 15352.27 & 97.62 & 0.00 & 146.71 & 0.00 \\
\hline Vegetation + DistCover + Elevation & 4 & 15360.67 & 106.02 & 0.00 & 155.11 & 0.00 \\
\hline Vegetation + DistCover & 5 & 15375.44 & 120.79 & 0.00 & 169.88 & 0.00 \\
\hline Vegetation + SWE $\times$ Vegetation + Distance & 7 & 15376.74 & 122.09 & 0.00 & 171.18 & 0.00 \\
\hline Vegetation + Elevation & 4 & 15395.31 & 140.66 & 0.00 & 189.75 & 0.00 \\
\hline Vegetation + SWE $\times$ Vegetation + Elevation & 7 & 15396.84 & 142.19 & 0.00 & 191.28 & 0.00 \\
\hline Vegetation & 3 & 15428.19 & 173.54 & 0.00 & 222.63 & 0.00 \\
\hline Vegetation + SWE $\times$ Vegetation & 6 & 15429.58 & 174.93 & 0.00 & 224.02 & 0.00 \\
\hline Vegetation $+\mathrm{PDSI}^{1} \times$ Vegetation & 6 & 15429.74 & 175.09 & 0.00 & 224.18 & 0.00 \\
\hline \multicolumn{7}{|l|}{ Grazing treatments model suite } \\
\hline Vegetation + Pasture + DistCover + Summer + Spring + Fall & 12 & 15205.56 & 0.00 & 0.67 & 0.00 & 0.67 \\
\hline Vegetation + Pasture + DistCover + Summer $\times$ PDSI + Spring $\times$ PDSI + Fall $\times$ PDSI & 15 & 15206.97 & 1.41 & 0.33 & 1.41 & 0.33 \\
\hline Vegetation + Pasture + DistCover + Summer & 11 & 15232.58 & 27.02 & 0.00 & 27.02 & 0.00 \\
\hline Vegetation + Pasture + DistCover + Summer $\times$ PDSI & 10 & 15233.91 & 28.35 & 0.00 & 28.35 & 0.00 \\
\hline
\end{tabular}

${ }^{1}$ SWE indicates snow water equivalence; PDSI, Palmer Drought Severity Index.

\section{RESULTS}

We observed a total of 2685 elk groups within the grazing system. Median group size was 42, and groups ranged in size from 1 to 2199 . Nine hundred groups were located in grasslands, 1633 were located in shrublands, 86 were located in forested areas, and 66 were located in other habitats. Mean distance to cover was $437 \mathrm{~m}$ (range: 0-1434 m). Mean elevation was $1852 \mathrm{~m}$ (range: $1706-2376 \mathrm{~m}$ ). During the study period, SWE averaged $30.8 \mathrm{~cm}$ and average seasonal SWE values ranged from $21.0 \mathrm{~cm}$ in 2007 to $74.5 \mathrm{~cm}$ in 1997. PDSI averaged -2.4 and average seasonal PDSI values ranged from -6.9 in 2003 to 4.7 in 1996.

The best model, as indicated by the lowest AIC score, that represented the effects of landscape features contained vegetation type, distance to cover, and pasture (Table 1). Elk groups selected for grasslands, shrublands, and other habitats over forested areas, and the strength of selection for grassland areas was strongest. Relative to selection for shrublands, the odds of an elk group selecting for grasslands were 1.41 (95\% $\mathrm{CI}=1.27,1.55)$ and the odds of a group selecting for forest were $0.12(95 \% \mathrm{CI}=0.10,0.16)$. Elk groups selected for areas farther from cover, although the estimated coefficient was $0.0008(95 \% \mathrm{CI}=0.0006,0.0009)$, indicating that distance to cover did not strongly affect resource selection. After the effects of vegetation type and distance to cover were accounted for, elk group selection for the six winter range pastures varied. In order of decreasing pasture preference, elk groups selected for NDH, BEG, LN, and UDH over LDH. The strength of selection for $\mathrm{LDH}$ and $\mathrm{LB}$ was similar.
The best model overall, as represented by the lowest AIC score, included both landscape features and a grazing effect (Table $1, w_{i}=0.67$ ). Selection coefficients representing effects of vegetation, distance to cover, and pasture were similar to the top-ranked model in the landscape features model suite (Table 2). Elk groups selected for rested pastures over springgrazed, summer-grazed, or fall-grazed pastures. Elk selection against the summer-grazed pastures was strongest, and the strength of selection for spring- and fall-grazed pastures was similar. Relative to selection for a spring-grazed area, the odds of a group selecting a summer-grazed area were $1.05(95 \%$ $\mathrm{CI}=0.89,1.26)$ and increased to $1.60(95 \% \mathrm{CI}=1.40,1.82)$ for a rested area (assuming grassland vegetation, mean distance to cover, and UDH pasture). The second-ranked model was within 1.41 $\triangle \mathrm{AIC}$ cells of the top model and contained all of the variables in the top-ranked model and a grazing and PDSI interaction (Table 2 ). The PDSI $\times$ growing season effect was positive $(\hat{\beta}=0.4,95 \% \mathrm{CI}=0.002,0.07)$, indicating that selection for areas grazed during the summer increased as PDSI increased. However, in spite of an increasing preference for areas receiving summer grazing following growing seasons with higher PDSI, the overall effect (main effect + interaction) of summer grazing on elk group selection remained negative. The confidence interval on the interaction terms representing interactive effects of PDSI and the other grazing cells each overlapped zero.

The proportion of the elk herd occupying the grazing system has remained consistent during the $19 \mathrm{yr}$ following implementation of the rest-rotation grazing system (Fig. 3). In the first 
Table 2. Results from resource selection analyses estimating effects of landscape features and grazing treatments on wintering elk resource selection at Wall Creek, Montana during 1988-2007. Coefficient estimates and 95\% confidence intervals are presented for the top ranked model within landscape features model suite and landscape features and grazing treatment model suite. Grassland was treated as the base vegetation type and forest, shrubland, and other represent the selection coefficients relative to grasslands. DistCover represents distance to cover. Pasture names are abbreviated and represent selection coefficients for the Bobcat English Gorge (BEG), Lower Bobcat English Gorge (LB), Lower Nickerson (LN), Nickerson Dry Hollow (NDH), and Upper Dry Hollow (UDH) pastures relative to the base category Lower Dry Hollow (LDH). Spring, summer, and fall represent the spring (May 1-June 1), summer (June 1-July 15), and fall (September 15-September 30) grazing treatments. Rested pastures were treated as the base category and spring, summer, and fall represent the selection coefficients for grazing treatments relative to the resting treatment.

\begin{tabular}{|c|c|c|c|c|c|c|}
\hline \multirow[b]{2}{*}{ Variable } & \multicolumn{3}{|c|}{ Landscape features suite } & \multicolumn{3}{|c|}{ Landscape features and grazing treatment suite } \\
\hline & Estimated coefficient & $95 \% \mathrm{LCl}^{1}$ & $95 \% \mathrm{UCl}^{1}$ & Estimated coefficient & $95 \% \mathrm{LCl}$ & $95 \%$ UCl \\
\hline Forest & -2.37 & -2.60 & -2.14 & 2.43 & 2.19 & 2.68 \\
\hline Shrubland & -0.11 & -0.20 & -0.01 & 2.34 & 2.11 & 2.57 \\
\hline Other & -0.60 & -0.84 & -0.35 & 1.94 & 1.60 & 2.27 \\
\hline DistCover & 0.0008 & 0.0006 & 0.0009 & 0.0008 & 0.0006 & 0.0009 \\
\hline BEG & 0.18 & 0.02 & 0.35 & 0.81 & 0.43 & 1.18 \\
\hline LB & -0.04 & -0.19 & 0.10 & -0.02 & -0.17 & 0.14 \\
\hline LN & 0.29 & 0.16 & 0.44 & 0.36 & 0.21 & 0.51 \\
\hline $\mathrm{NDH}$ & 0.81 & 0.65 & 0.98 & 1.32 & 0.94 & 1.70 \\
\hline UDH & 0.22 & 0.09 & 0.36 & 0.73 & 0.37 & 1.10 \\
\hline Summer & - & - & - & -0.41 & -0.54 & -0.29 \\
\hline Spring & - & - & - & -0.22 & -0.35 & -0.09 \\
\hline Fall & - & - & - & -0.27 & -0.36 & -0.17 \\
\hline
\end{tabular}

${ }^{1} \mathrm{LCl}$ indicates lower confidence interval; $\mathrm{UCl}$, upper confidence interval.

year following implementation of the grazing system, an average of $55 \%(95 \% \mathrm{CI}=40 \%, 69 \%)$ of the total herd occupied the grazing system. In 2007, $19 \mathrm{yr}$ after implementation of the grazing system, $49 \%(95 \% \mathrm{CI}=40 \%, 59 \%)$ of the total herd occupied the grazing system. During the study period, the number of elk in the Wall Creek herd increased from approximately 1200 animals to 3000 animals. The number of elk using the grazing system increased from an average of $773(95 \% \mathrm{CI}=673,872)$ during 1988-1990 (the first $3 \mathrm{yr}$ following implementation of the grazing system) to $1243(95 \% \mathrm{CI}=1092,1393)$ in $2005-2007$. Overall, the number of elk utilizing the grazing system has increased proportional to increases in the Wall Creek elk herd size.

\section{DISCUSSION}

We found that a rest-rotation grazing system implemented on an ungulate winter range had minimal effects on overall wintering elk herd distribution, but did result in subtle shifts
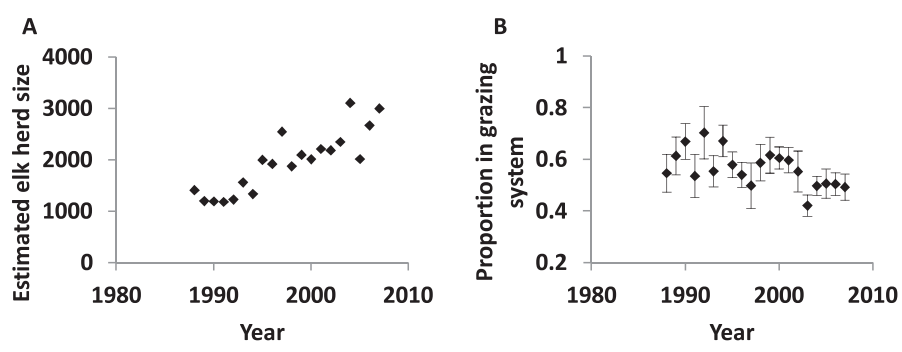

Figure 3. A, The estimated size of the Wall Creek elk herd and B, average annual proportion of the herd utilizing the Wall Creek grazing system, from 1988 to 2007. Error bars represent the standard error around the mean. in elk distributions within the grazing system. No large-scale shifts in elk distributions into or out of the grazing system from other portions of the winter range were observed. Within the grazing system, elk groups selected for rested pastures, suggesting that rested pastures may retain valuable forage for wintering ungulates and should be maintained in grazing systems existing on ungulate winter ranges. Although we found wintering elk groups preferred rested pastures, grazed pastures may help establish important early spring and summer forage for elk during the calving season (Frisina 1992). Our study evaluated effects of grazing cells on wintering elk, and effects of grazing cells during other seasons may have differed. For example, in the nearby Fleecer Wildlife Management Area grazing system, movement of livestock off of the spring-grazed pastures occurs before the growing season and vegetation in the spring-grazed pasture has ample opportunity for regrowth. In this system, we may expect elk group selection for both rested and spring-grazed pastures to be similar, as livestock are not reducing availability of forage in the spring-grazed pastures. Further, winter snowpack conditions likely have a strong influence on overall elk distributions (Messer et al. 2009), although when using a coarse landscape-level estimate of SWE, we did not detect effects of snowpack on fine-scale elk group distributions.

We found support for our prediction that wintering elk groups would select against pastures grazed during the previous summer growing season, presumably in response to the reduced amount of forage available due to consumption by livestock. Further, we found limited evidence that the effects of growingseason grazing were dependent upon growing-season conditions. Elk selection for areas grazed during the growing season was greater following years with wetter growing season conditions than following years with drought conditions during the growing season. During better growing-season conditions (i.e., 
less drought as measured by PDSI), an increased abundance of quality forage may be produced, and the effects of livestock grazing on forage availability for winter elk may be diminished. This result indicates that growing-season conditions should be considered in future studies evaluating effects of grazing on wildlife.

Our results also indicated that elk groups preferred the rested pastures over the spring- and fall-grazed pastures. Some authors have postulated that spring grazing may increase nutrient content of winter forage for elk by delaying senescence (Anderson and Scherzinger 1975). Plants grazed in the spring may retain nutrients, which would be available for wintering elk, rather than translocate nutrients into their root systems before winter. Although we did not directly evaluate nutrient composition, elk select for the most palatable forage (Alldredge et al. 2002), and we did not find evidence that wintering elk groups preferentially selected for pastures that had been grazed the previous spring. Our findings support previous work in a similar bunchgrass-dominated system concluding that spring grazing did not significantly increase forage nutrients available for wintering elk (Wambolt et al. 1997). In the Wall Creek restrotation grazing system, the timing of the spring grazing treatment may not have allowed ample time for plant regrowth. Preference for the rested pastures suggests that amount of forage available supersedes any benefit elk would receive from increased nutrient content, if increased nutrient content did occur. The maintenance of abundant forage in rested pastures may be particularly important, as late winter may be a critical time for ungulates because nutrient reserves may become depleted and nutritional demands for gestation increase (Parker et al. 2009). Additionally, although the fall grazing treatment was a short-duration treatment, elk group selection for rested pastures over fall-treated pastures suggests that the fall treatment did reduce the forage availability for elk the following winter.

The coordinated management program at Wall Creek was developed with the goals of maintaining high-quality forage for wintering elk, reducing elk and cattle competition on critical elk winter range, allowing for maintenance and enhancement of vegetative resources, and enhancing the desirability of Wall Creek WMA for elk to alleviate game damage problems on adjacent private land (Alt et al. 1992). The increasing number of elk using the grazing system during the $19 \mathrm{yr}$ following implementation of the rotation grazing system indicates that the grazing system is meeting the objectives of providing quality forage for wintering elk and maintaining vegetation resources. This result is consistent with a previous study in southwestern Montana that also found increasing elk utilization of the grazed portion of a winter range in the years following implementation of a rotation grazing system (Frisina and Morin 1991). Although a greater number of elk have used the grazing system in the $19 \mathrm{yr}$ following system implementation, the increase in use was proportional to the overall increase in herd size with only about half the herd using the grazing system. Therefore, at the current elk numbers the publically owned portion of winter range that employs the coordinated grazing system may be insufficient in size to aggregate animals and substantially reduce game damage claims on adjacent lands. We were unable to evaluate if the grazing system enhanced vegetative resources. If the grazing system enhanced vegetation over time, elk group selection for the most beneficial treatments should decline over time, because the difference in elk food among treatments should decline over time. However, we did not explicitly evaluate this prediction because elk herd size also increased over time, and disentangling the effects of increasing herd size and improved vegetative resources was not possible.

\section{IMPLICATIONS}

We recommend that wildlife managers employing livestock grazing systems on ungulate winter range maintain rested pastures in existing rotational grazing systems. Our results indicate that elk select for these pastures, which likely conserve essential winter forage for ungulates. Our results do not indicate that resting the entire grazing system would benefit elk and this distinction is important to understand. Rested pastures were rested pastures within a grazing system, not ungrazed pastures. During the 21-yr time period when the Wall Creek WMA was rested from livestock grazing, elk use of the area was limited and game damage complaints on adjacent lands increased (Alt et al. 1992). Therefore, it is unlikely that resting the entire area would improve vegetative resources for elk. Our results instead indicate that within the grazing system, grazed pastures rested during the previous year are selected for by wintering elk. Further, the Wall Creek grazing system is relatively unique and effects of grazing cells on wintering elk distributions may differ elsewhere.

Elk group preference for rested pastures within the grazing system may be an effective tool for shifting the distribution of wintering elk from adjacent private lands to publically owned lands employing rotation grazing systems. At lower elk herd sizes, elk group selection for rested pastures may aggregate animals in the rested pastures and alleviate game damage on adjacent private lands. Additionally, rested pastures provide important cover for a variety of species (Douglass and Frisina 1993; Derner et al. 2009; Krausman et al. 2009), and may increase species richness and abundance (Giuliano and Homyack 2004) and improve ecosystem processes (Sanjari et al. 2009). The implementation of rest-rotation grazing systems allows some livestock grazing on lands managed for wildlife. The collaboration between wildlife and livestock managers to maintain grazing systems on lands managed for wildlife may also foster cooperation between the two groups. Given the ubiquitous nature of livestock grazing in the western United States, this could have important landscape-scale implications for wildlife management.

\section{ACKNOWLEDGMENTS}

We thank J. Egan, A. Foss, M. Frisina, G. Hormay, and R. Schott for helping design and implement the grazing system, and for logistical support. J. Cunningham and K. Hughes provided valuable insight on project development, and J. Gude and M. Frisina provided helpful comments on this manuscript.

\section{LITERATURE CITED}

Alldredge, M. W., J. M. Peek, And W. A. Wall. 2002. Nutritional quality of forages used by elk in northern Idaho. Journal of Range Management 55:253-259. 
Alt, K. L., M. R. Frisina, and F. J. King. 1992. Coordinated management of elk and cattle, a perspective-Wall Creek Wildlife Management Area. Rangelands 14:12-15.

Anderson, E. W., AND R. J. Scherzinger. 1975. Improving quality of winter forage for elk by cattle grazing. Journal of Range Management 28:120-125.

Briske, D. D., J. D. Derner, J. R. Brown, S. D. Fuhlendorf, W. R. Teague, K. M. Havstad, R. L. Gillen, A. J. Ash, and W. D. Willms. 2008. Rotational grazing on rangelands: reconciliation of perception and experimental evidence. Rangeland Ecology \& Management 61:3-17.

Brown, J., and M. Kothmann. 2009. Rotational grazing and the profession and practice of rangeland management. Rangelands 31:3-4.

Burnham, K. P., and D. R. Anderson. 2002. Model selection and multimodel inference a practical information-theoretic approach. 2nd ed. New York, NY, USA: Springer Science and Business Media, Inc. 488 p.

Coppock, D. L., J. K. Detling, J. E. Eluis, and M. I. Dyer. 1983. Plant-herbivore interactions in a North American mixed-grass prairie. Oecologia 56:1-9.

Coughenour, M. B. 1991. Biomass and nitrogen responses to grazing of upland steppe on Yellowstone's northern winter range. Journal of Applied Ecology 28:71-82.

Derner, J. D., W. K. Lauenroth, P. Stapp, and D. J. Augustine. 2009. Livestock as ecosystem engineers for grassland bird habitat in the western Great Plains of North America. Rangeland Ecology \& Management 62:111-118.

Detling, J. K., M. I. Dyer, and D. T. Winn. 1979. Net photosynthesis, root respiration, and regrowth of Bouteloua gracilis following simulated grazing. Oecologia 41:127-134.

Douglass, R. J., and M. R. Frisina. 1993. Mice and management on the Mount Haggin Wildlife Management Area. Rangelands 15:8-12.

FleischneR, T. L. 1994. Ecological costs of livestock grazing in western North America. Conservation Biology 8:629-644.

FrISINA, M. R. 1992. Elk habitat use within a rest-rotation grazing system. Rangelands 14:93-96.

Frisina, M. R., And F. G. Morin. 1991. Grazing private and public land to improve the Fleecer elk winter range. Rangelands 13:291-294.

Ganskopp, D., R. Angell, AND J. Rose. 1992. Response of cattle to cured reproductive stems in a Caespitose grass. Journal of Range Management 45:401-404.

Giuliano, W. M., AND J. D. Homyack. 2004. Short-term grazing exclusion effects on riparian small mammal communities. Journal of Range Management 57:346-350.

Hamlin, K., AND M. Ross. 2002. Effects of hunting regulation changes on elk and hunters in the Gravelly-Snowcrest Mountains, Montana. Helena, MT, USA Montana Department of Fish, Wildlife, and Parks. Federal Aid in Wildlife Restoration Project W-120-R. 237 p.

HOLECHEK, J. L. 1988. An approach for setting the stocking rate. Rangelands 10:10-14.

Holechek, J. L., R. Valdez, S. D. Schemnitz, R. D. Pieper, and C. A. Davis. 1982. Manipulation of grazing to improve or maintain wildlife habitat. Wildlife Society Bulletin 10:204-210.
Hormay, A. L. 1970. Principles of rest-rotation grazing and multiple use land management. Washington, DC, USA: US Government Printing Office. 1970 0385-056, US Forest Service Training Text No. 4 (2200). 25 p.

Jaramillo, V. J., and J. K. Detling. 1988. Grazing history, defoliation, and competition: effects on shortgrass production and nitrogen accumulation. Ecology 69:1599-1608.

Krausman, P. R., D. E. Naugle, M. R. Frisina, R. Northrup, V. C. Bleich, W. M. Block, M. C. Wallace, And J. D. WRight. 2009. Livestock grazing, wildlife habitat, and rangeland values. Rangelands 31(5):15-19.

Mao, J. S., M. S. Boyce, D. W. Smith, F. J. Singer, D. J. Vales, J. M. Vore, and E. H. MerRILL. 2005. Habitat selection by elk before and after wolf reintroduction in Yellowstone National Park. Journal of Wildlife Management 69:1691-1707.

McNaughton, S. J. 1983. Compensatory plant growth as a response to herbivory. Oikos 40:329-336.

Merrill, E. H., N. L. Stanton, and J. C. Hak. 1994. Responses of bluebunch wheatgrass, Idaho fescue, and nematodes to ungulate grazing in Yellowstone National Park. Oikos 69:231-240.

Messer, M. A., R. A. Garrott, S. Cherry, P. J. White, F. Watson, and E. Merideth. 2009. Elk winter resource selection in a severe snowpack environment. In: R. A. Garrott, P. J. White, and F. G. R. Watson [EDS.]. The ecology of large mammals in central Yellowstone: sixteen years of integrated field studies. San Diego, CA, USA: Elsevier, Academic Press. p. 137-156

Milchunas, D. G., and W. K. Lauenroth. 1993. Quantitative effects of grazing on vegetation and soils over a global range of experiments. Ecological Monographs 63:327-366.

National Climate Data Center. 2010. Index of publications and data. Available at: http:/www1.ndc.noaa.gov/pub/data/cirs/. Accessed 13 September 2010.

Parker, K. L., P. S. Barboza, and M. P. Gillingham. 2009. Nutrition integrates environmental responses of ungulates. Functional Ecology 23:57-69.

Proffitt, K. M., J. Grigg, R. A. Garrott, J. Gude, J. Cunningham, and K. L. Hamlin. 2011. Elk distribution and spatial overlap with livestock during the brucellosis transmission risk period. Journal of Applied Ecology 48:471-478.

Sanjari, G., B. Yu, H. Ghadiri, C. A. A. Ciesiolka, and C. W. Rose. 2009. Effects of time-controlled grazing on runoff and sediment loss. Australian Journal of Soil Research 47:796-808.

SAYre, N. F. 2009. Bad abstractions: response to Sullivan. Conservation Biology 23:1050-1052.

SuluIVAN, B. K. 2009. The greening of public lands grazing in the southwestern USA Conservation Biology 23:1047-1049.

Wambolt, C. L., M. R. Frisina, K. S. Douglass, and H. W. Sherwood. 1997. Grazing effects on nutritional quality of bluebunch wheatgrass for elk. Journal of Range Management 50:503-506.

WUeRTHNeR, G. 1992. Wall Creek game range-a dissenting view. Rangelands $14: 8-11$. 